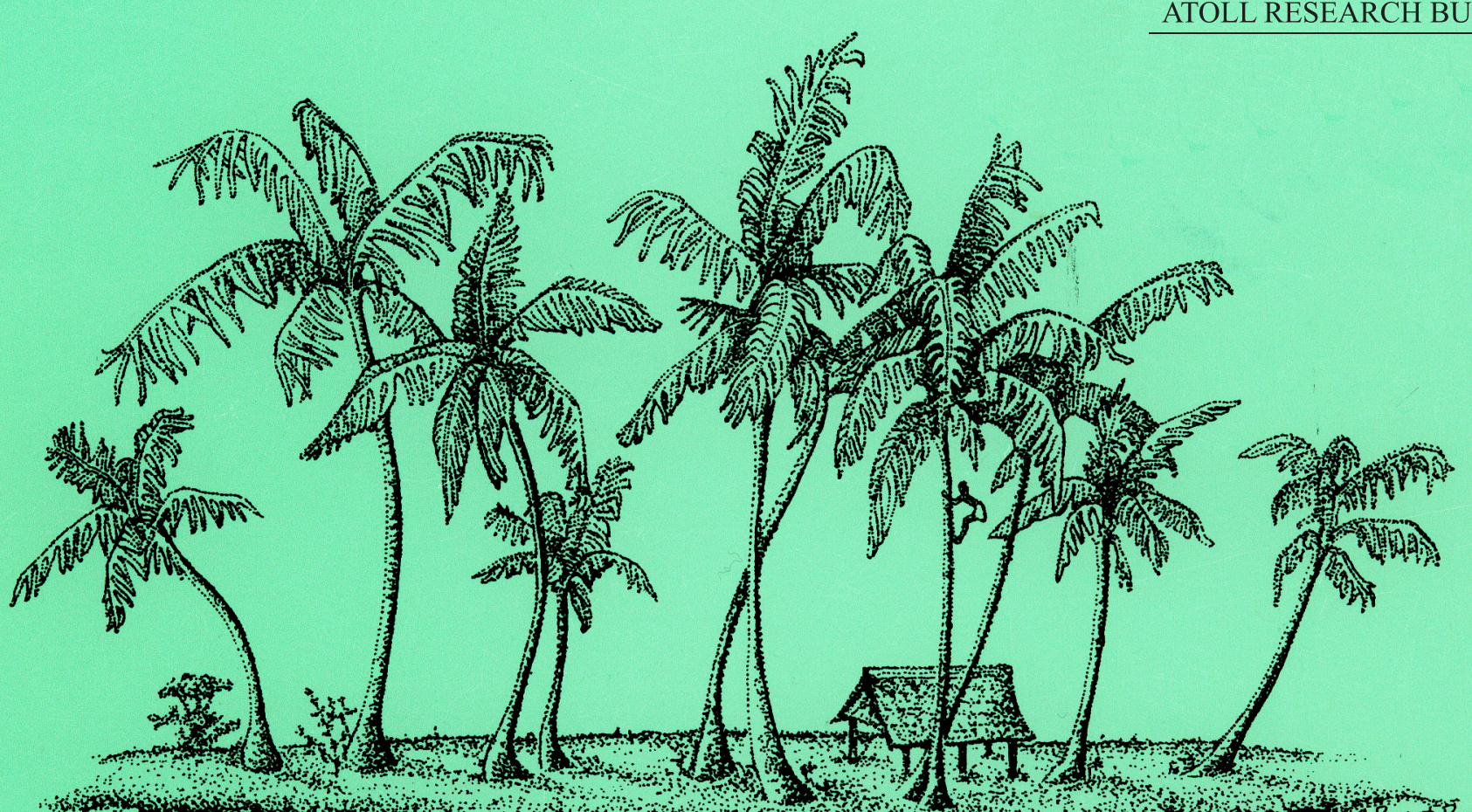

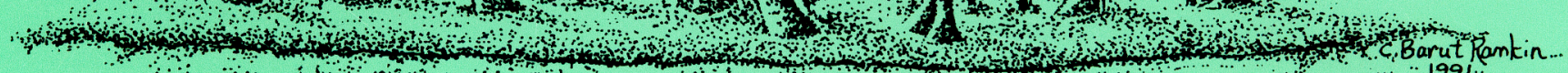

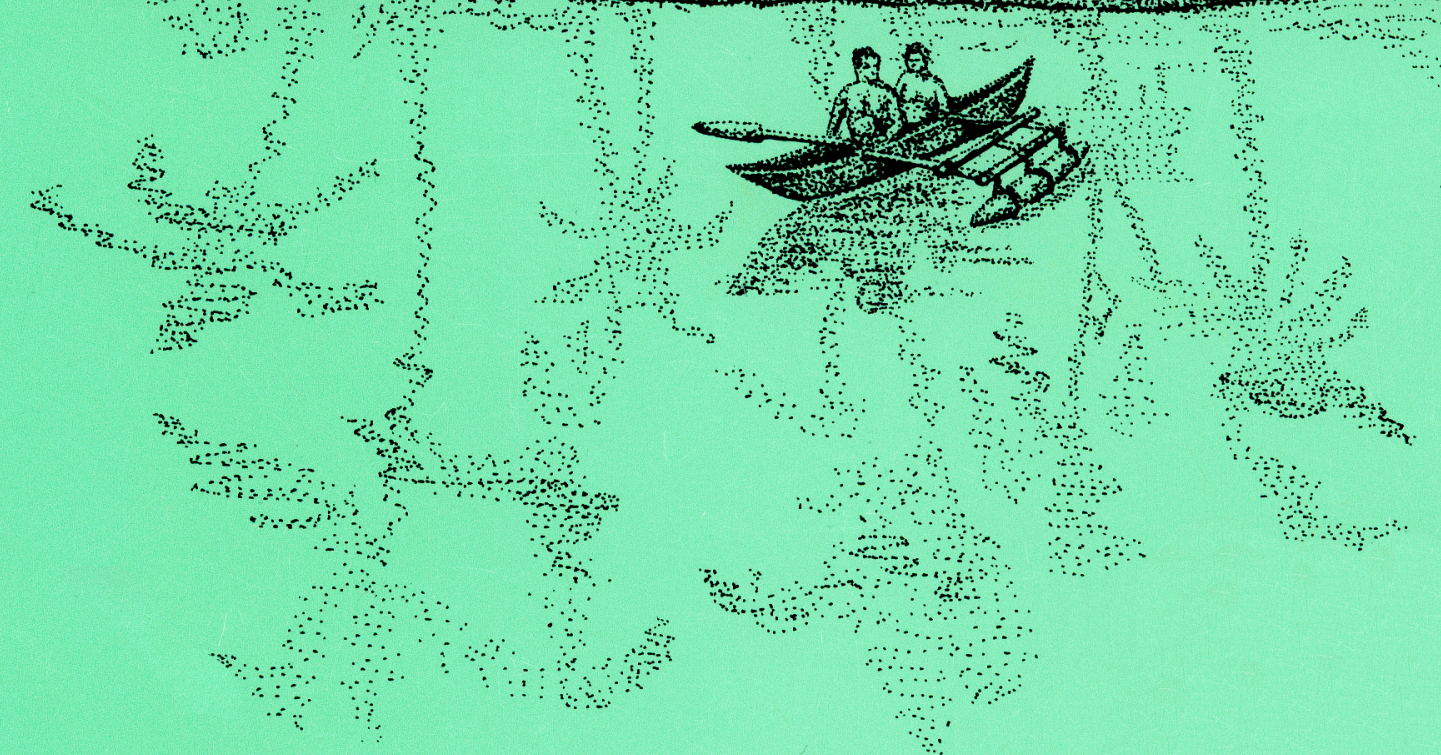

SHELL DIMENSION-LIVE WEIGHT RELATIONSHIPS, GROWTH AND SURVIVAL OF HIPPOPUS PORCELLANUS

IN TUBBATAHA REEFS NATURAL PARK, PHILIPPINES

Roger G. Dolorosa, Segundo F. Conales, and Noel A. Bundal

Smithsonian Institution

Scholarly Press

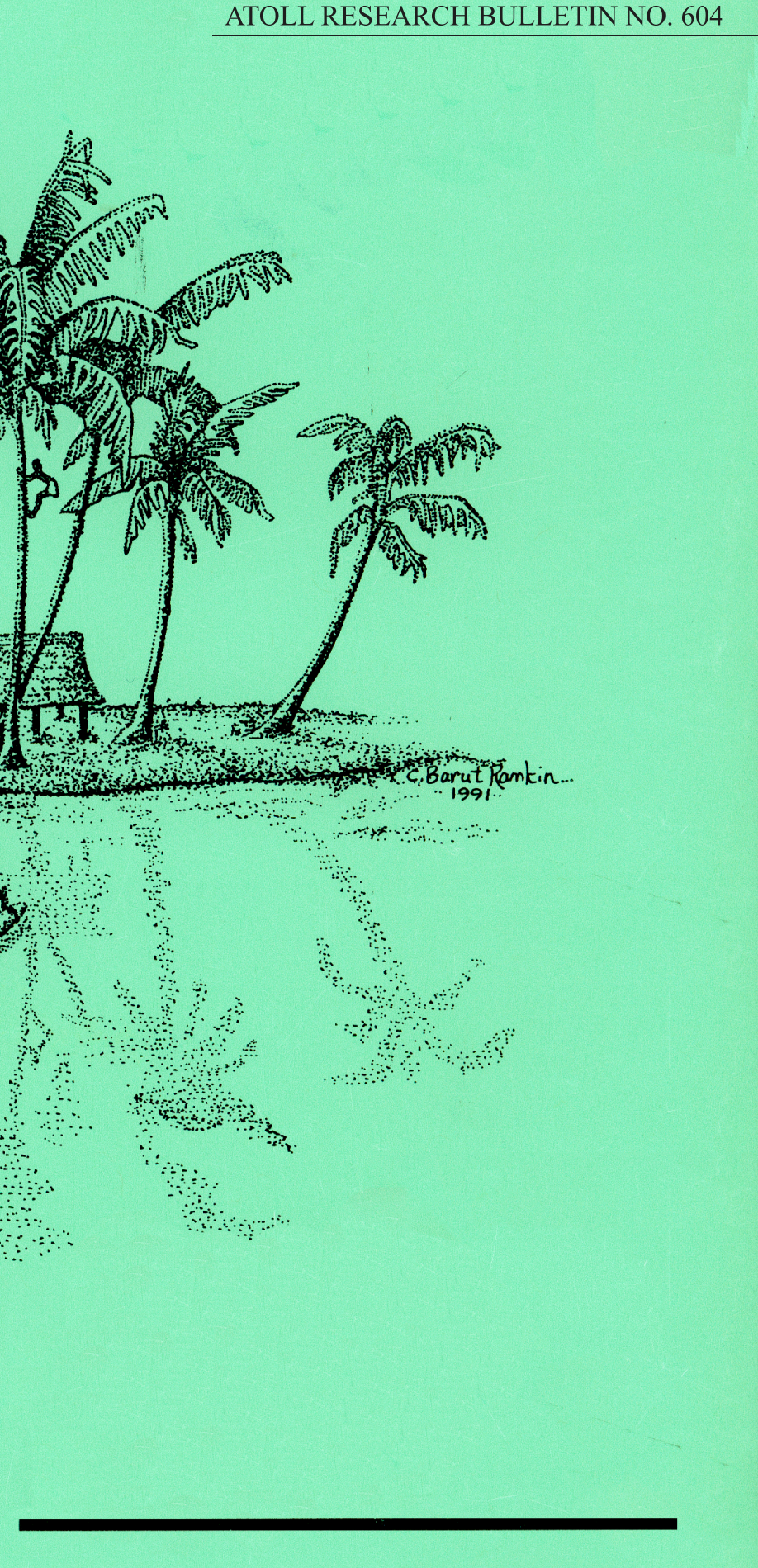

\section{ATOLL}

RESEARCH

BULLETIN 


\section{SHELL DIMENSION-LIVE WEIGHT RELATIONSHIPS, GROWTH AND SURVIVAL OF HIPPOPUS PORCELLANUS IN TUBBATAHA REEFS NATURAL PARK, PHILIPPINES}

Roger G. Dolorosa, Segundo F. Conales, and Noel A. Bundal

Atoll Research Bulletin No. 604 23 July 2014 
All statements made in papers published in the Atoll Research Bulletin are the sole responsibility of the authors and do not necessarily represent the views of the Smithsonian Institution or of the editors of the Bulletin. Articles submitted for publication in the Atoll Research Bulletin should be original papers and must be made available by authors for open access publication. Manuscripts should be consistent with the "Author Formatting Guidelines for Publication in the Atoll Research Bulletin." All submissions to the Bulletin are peer reviewed and, after revision, are evaluated prior to acceptance and publication through the publisher's open access portal, Open SI (http://opensi.si.edu).

Published by SMITHSONIAN INSTITUTION SCHOLARLY PRESS

P.O. Box 37012, MRC 957

Washington, D.C. 20013-7012

www.scholarlypress.si.edu

The rights to all text and images in this publication are owned either by the contributing authors or third parties. Fair use of materials is permitted for personal, educational, or noncommercial purposes. Users must cite author and source of content, must not alter or modify the content, and must comply with all other terms or restrictions that may be applicable. Users are responsible for securing permission from a rights holder for any other use.

ISSN: 0077-5630 (online) 


\title{
SHELL DIMENSION-LIVE WEIGHT RELATIONSHIPS, GROWTH AND SURVIVAL OF HIPPOPUS PORCELLANUS IN TUBBATAHA REEFS NATURAL PARK, PHILIPPINES
}

\author{
ROGER G. DOLOROSA ${ }^{1}$, SEGUNDO F. CONALES ${ }^{2}$, and NOEL A. BUNDAL ${ }^{2}$
}

\begin{abstract}
Hippopus porcellanus is a rare and heavily exploited giant clam species with limited distribution range in the Indo-West Pacific Region. Overharvesting has resulted in the localized extinction of $H$. porcellanus in the Philippines, but its populations appeared to have recovered in Tubbataha Reefs Natural Park (TRNP) after more than 20 years of protection. As one of the least studied giant clam species, the shell dimension-live weight relationships were determined. In addition, the growth parameters of $H$. porcellanus in TRNP were monitored with the mark-recapture method. All three shell dimensions of $H$. porcellanus were good estimators of live weight. The von Bertallanfy growth parameters $K(0.29)$ and $L \infty$ $(29.24 \mathrm{~cm})$ were determined on the basis of 80 marked individuals recaptured twice within 2.5 years. Nearly $90 \%$ of marked clams survived at the end of the study. Studies on aspects of biology of other giant clams species at the park is suggested.
\end{abstract}

Keywords: Giant clam, growth, Hippopus porcellanus, mark-recapture, survival, Tubbataha Reefs Natural Park

\section{INTRODUCTION}

Giant clams (Cardiidae: Tridacninae), with only 11 extant species (Othman et al., 2010; Su et al., 2014) worldwide, are the largest living bivalves that for centuries have been utilized as food and their shells as ornaments. However, excessive harvesting of these clams for external trade has led to local extinctions of several species in the Philippines, Micronesia, Singapore and Indonesia (see Tan and Zulfigar, 2003; Gomez and Mingoa-Licuanan, 2006; Othman et al., 2010; Neo and Todd, 2013). All giant clams are listed in Appendix II of the Convention on International Trade in Enganged Species of Wild Fauna and Flora (CITES, 2014).

Hippopus porcellanus and the newly discovered three giant clam species Tridacna costata, Tridacna rosewateri and Tridacna teveroa have the most restricted geographical ranges (Othman et al., 2010), making them more vulnerable to harvesting. In the Philippines, $H$. porcellanus has been reported only in the southern parts of Mindanao (Othman et al., 2010, Poutiers 1998b) and the Palawan group of islands (Villanoy et al., 1988). In 1993, only empty shells of H. porcellanus, H. hippopus and Tridacna derasa were encountered by Estacion et al. (1993) in Tubbataha Reefs Natural Park (TRNP). In the same year, Calumpong and Cadiz (1993) found a few individuals of $H$. porcellanus, suggesting that the species is rarely present or has been overexploited in the reefs of Tubbataha.

Efforts to conserve and restore the natural populations of giant clams have led to the study of their biology, propagation and restocking (Basker, 1991; Foyle et al., 1997; Gomez and Mingoa-Licuanan, 2006; Hart et al., 1998). However, the rare occurrence of $H$. porcellanus have made it difficult to understand its biology in captivity and in the wild. Juinio et al. (1989) reported that $H$. porcellanus were

${ }^{1}$ College of Fisheries and Aquatic Sciences, Western Philippines University-Puerto Princesa Campus, Sta. Monica, Puerto Princesa City 5300, Philippines. Email: rogerdolorosa@yahoo.com

${ }^{2}$ Tubbataha Management Office, Abad Santos St., 5300 Puerto Princesa City, Philippines. 
so rare that they failed to find breeders for propagation and restocking projects. Information obtained from studies involving bivalve growth, survival and shell dimensions-live weight relationships are important in resource management and in monitoring changes in environmental conditions (see Gimin et al., 2004; Watson et al., 2012). With the recovery of H. porcellanus populations in TRNP (Dolorosa and Jontila, 2012) after more than two decades of protection, this study sought to investigate some aspects of its biology such as shell dimension-live weight relationships, growth and survival.

\section{MATERIALS AND METHODS}

\section{The Study Site}

The study site was at the southern tip of the North Atoll of TRNP, Philippines (Figure 1), no more than $1 \mathrm{~km}$ away from the Ranger Station. It formed part of the shallow subtidal reef along the edge of the lagoon.

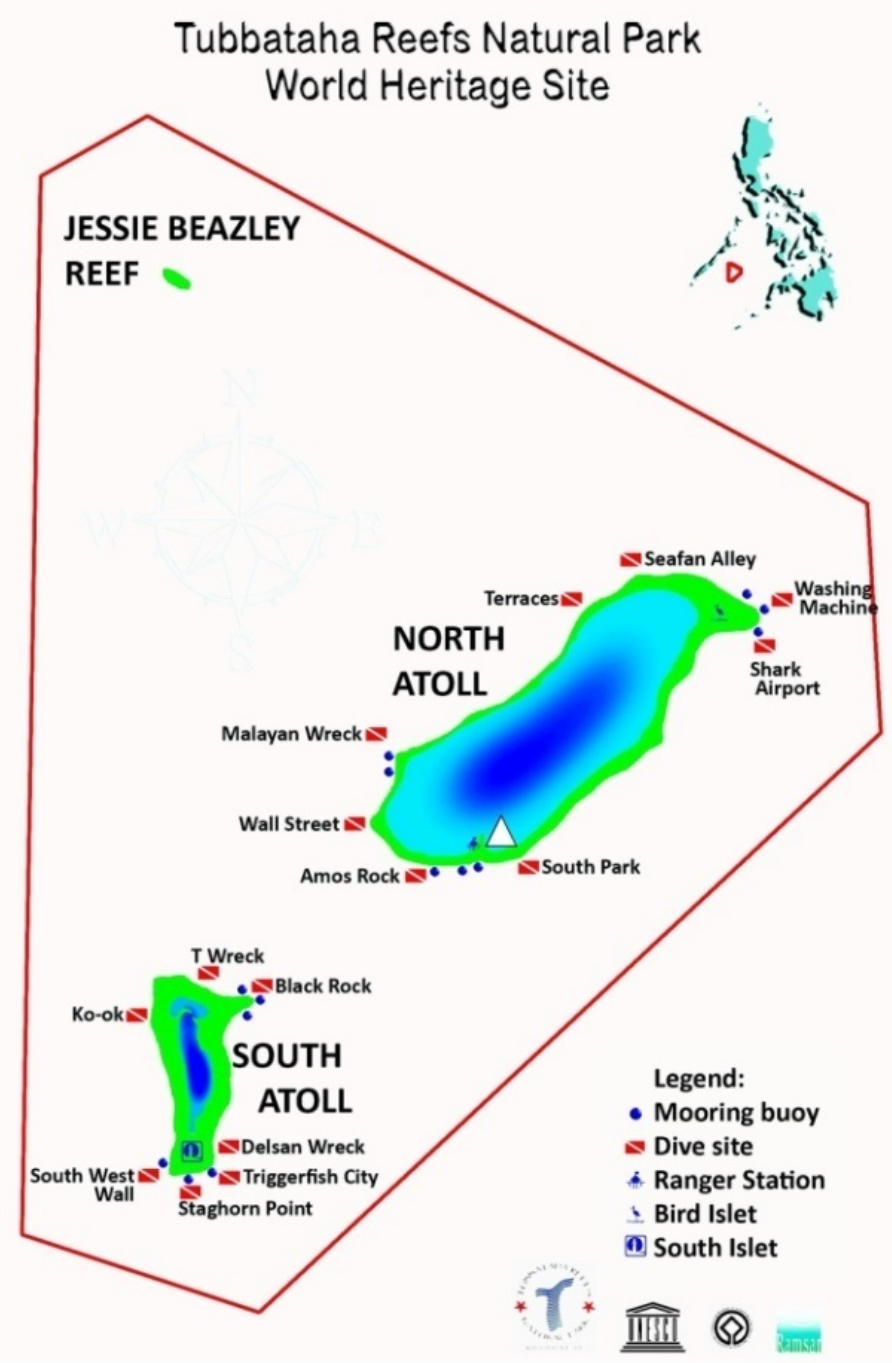

Figure 1. Dive map of Tubbataha Reefs Natural Park and the study site (white triangle) at the souther tip of the North Atoll. Map credit: Tubbataha Management Office. 
The area was up to about $1 \mathrm{~m}$ deep at low tide with patches of massive and branching corals. Massive corals which dot the area were exposed during extreme low tides. Its sandy substrate shifts seasonally and poses hazards to the clams along the lowtide water margin. The area is also close to one of the translocation studies for the reef gastropod Trochus niloticus (Dolorosa et al., 2013).

\section{Tagging and Sampling}

Naturally occuring giant clams in the area were collected on 29 December 2009 and brought to the Ranger Station for cleaning, measurement and tagging. In total, 100 clams of varied sizes (Range: 8.2$31.3 \mathrm{~cm}$; Mean: $21.98 \mathrm{~cm}$; sd: $5.27 \mathrm{~cm}$ ) were tagged. Tagging was done by first removing the marine growths on the shell with the aid of a steel brass before a prenumbered dymo tag was glued on the shell with marine epoxy (Figure 2 left photo). The clams were temporarily kept under the Ranger Station to protect them from exteme sunlight while allowing the tag to harden for a few hours. To avoid stress the clams were returned to their original habitat before sundown.

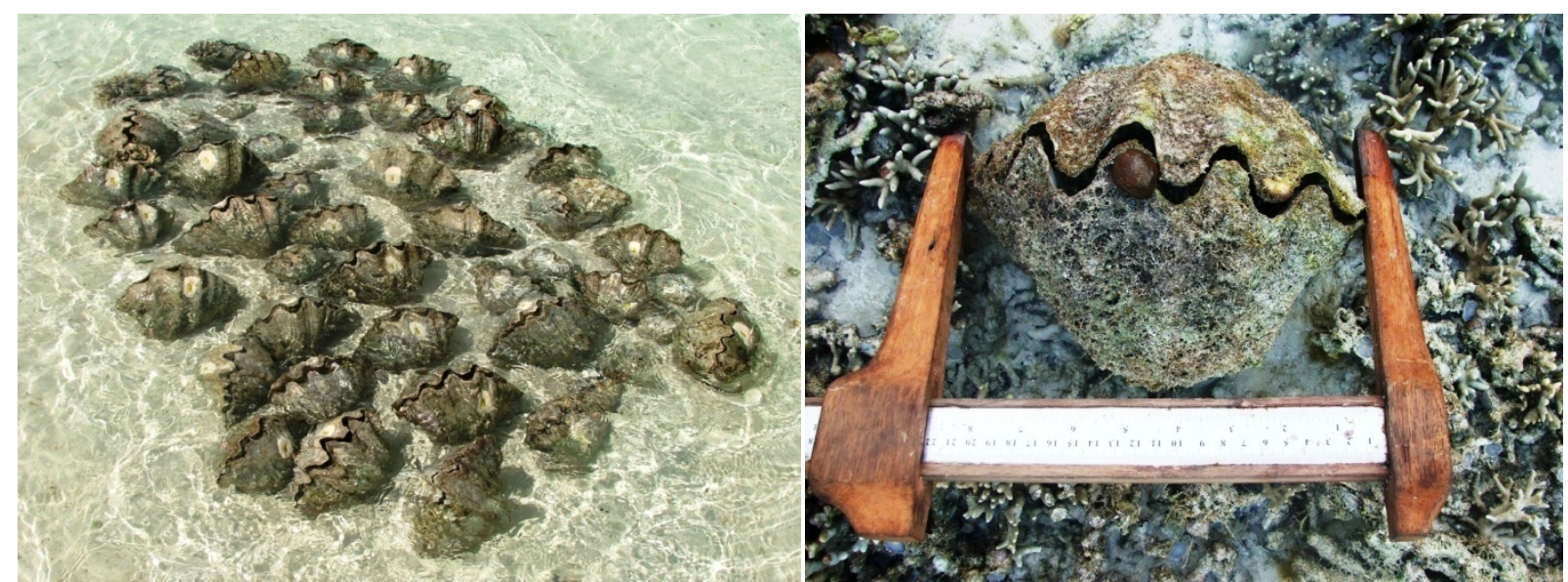

Figure 2. The newly marked Hippopus porcellanus ready to be returned in their natural habitat (left) and in situ shell length measurement (right).

During initial measurements, shell dimensions such as length, height and inflation of each clam were determined to the nearest $0.1 \mathrm{~cm}$ with calipers. The live weight of each clam was measured with a spring balance. On two succeeding events, only the shell lengths were measured (Figure 2, right photo). No measurements were taken from dead individuals and those with unrecognized and damaged tags.

\section{Analysis}

Shell dimensions (length, height and inflation) and live weight measurements obtained in December 2009 were subjected to regression analysis to derive shell dimension - live weight relationships.

Increase in size of giant clams at every measurement event was computed based on a total of 80 clams with complete records of shell lengths in all three events. Mean sizes of the clams were compared using analysis of variance and Scheffé post hoc tests with the use of R version 2.12.0 (R, 2011). Growth parameters such as the average maximum attainable shell length $(\mathrm{cm} ; L \infty)$ and the Brody growth coefficient $(K)$ for $H$. porcellanus were obtained using the formula of Fabens (Ogle, 2010):

$$
L r=L m+(L \infty-L m)\left(1-e^{-k \delta t}\right)
$$


where $L m$ stands for the size of clams at the time of marking; $L r$ represents the recorded size at the time of recapture; and $\delta t$ stands for the difference in size between recapture and time at marking or between the second and first recaptures. The time intervals (days) between sampling were converted into years by dividing the data by 365 days. To determine the size of giant clams at a particular age, the estimated growth parameters $(K$ and $L \infty)$ were then substituted into the von Bertalanffy growth formula (VBGF) (Ogle, 2010),

$$
L t=L \infty\left(1-e^{-k(t-t 0)}\right)
$$

where $L t$ is the size at time $t$ and $t_{0}$ is the theoretical age at size zero. Unknown parameters were determined with the use of FSA package (Ogle, 2010) in R version 2.12.0 (R, 2011).

\section{RESULTS}

\section{Shell Dimension-Live Weight Relationships}

The relationships between the different shell dimensions and live weight of $H$. porcellanus were best expressed by the equation $W=a L^{b}$, where $W$ stands for live weight and $L$ for any of the three shell dimensions. The variable $a$ represents the $y$-axis value when the $x$-axis is zero; $b$ is the slope of the regression equation. The derived equations suggest that $93.3-96.7 \%$ of the changes in the live weight of H. porcellanus is influenced by the change in shell dimensions (Figure 3 ).

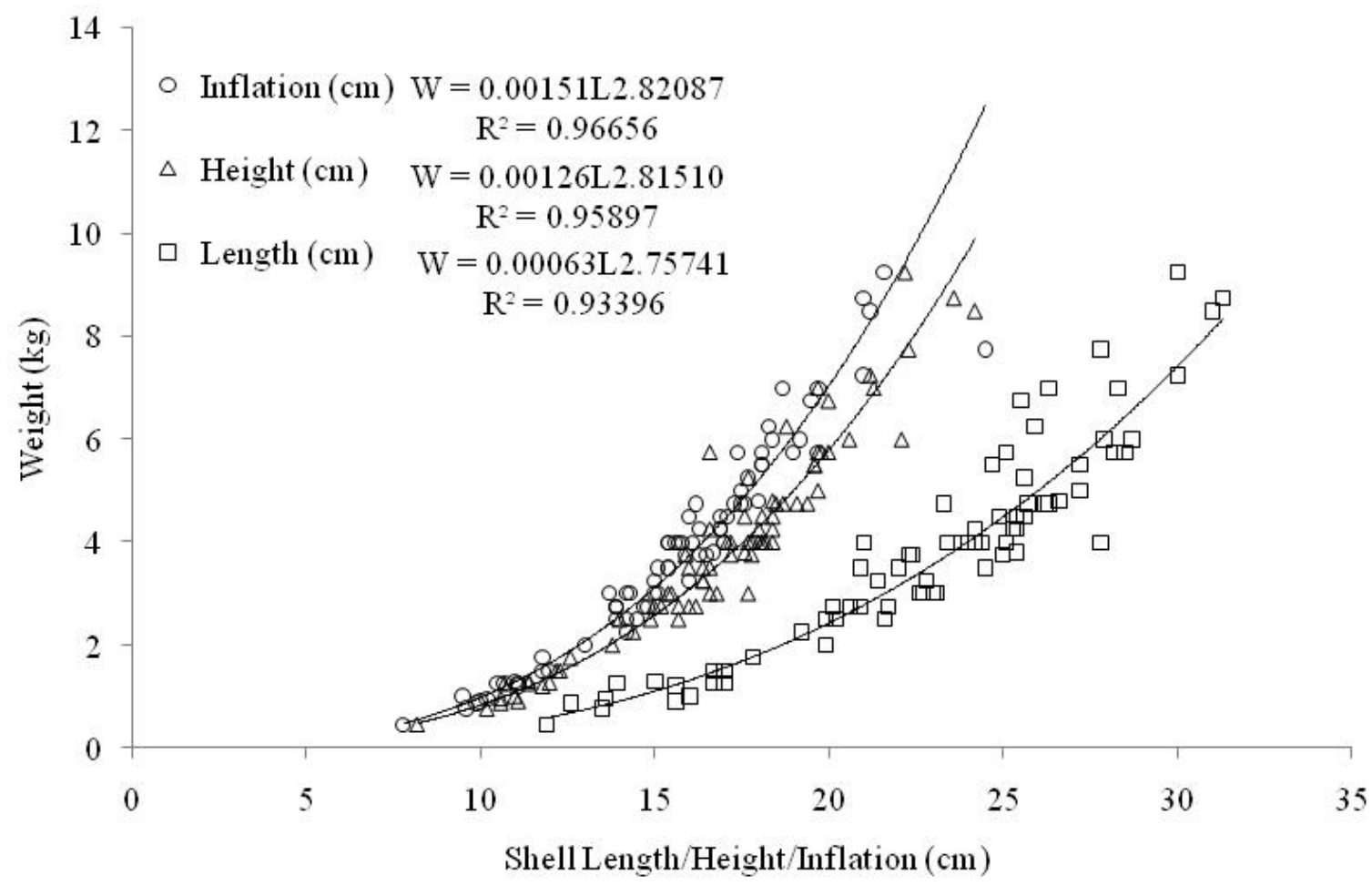

Figure 3. Relationships between shell dimensions (length, height, inflation) and live shell weight of Hippopus porcellanus in TRNP. 


\section{Growth and Survival}

On average, the shell length of $H$. porcellanus increased by $3 \mathrm{~cm}$ in 2.5 years, or about $1.2 \mathrm{~cm}$ per year. The mean shell lengths at three measurement events were significantly different as suggested by ANOVA tests $(\mathrm{P}<0.01)$, but Scheffe post hoc tests found no significant difference $(\mathrm{P}>0.05)$ between means in the second and third measurementevents (Table 1). The predicted average maximum length $L \infty$ $=29.24 \mathrm{~cm}$ and growth constant $K=0.24$ when substituted to the VBGF suggested a rapid growth in the first five years, reaching about $22.30 \mathrm{~cm}$ or $76.27 \%$ of its $L \infty$. Annual growth rate declined by about $25 \%$, suggesting that $L \infty$ would be attained in approximately 20 years (Figure 4 ).

Table 1. Mean increase in size of marked Hippopus porcellanus with complete shell length (SL) records $(\mathrm{n}=80)$ for the duration of the study. Similar superscripts are not significantly different.

\begin{tabular}{|l|c|c|c|c|c|c|c|}
\hline Sampling & Date & $\begin{array}{c}\text { Number of } \\
\text { days from } \\
\text { tagging }\end{array}$ & $\begin{array}{c}\text { No. of } \\
\text { ind. }\end{array}$ & $\begin{array}{c}\text { Mean SL } \\
(\mathrm{cm})\end{array}$ & sd & $\begin{array}{c}\text { Min. SL } \\
(\mathrm{cm})\end{array}$ & $\begin{array}{c}\text { Max. SL } \\
(\mathrm{cm})\end{array}$ \\
\hline Initial & 29 Dec 09 & 0 & 80 & $22.92^{\mathrm{a}}$ & 4.52 & 8.2 & 31.3 \\
\hline Second & 21 Dec 10 & 357 & 80 & $24.52^{\mathrm{b}}$ & 3.79 & 14.2 & 31.8 \\
\hline Third & 13 Jun 12 & 897 & 80 & $25.92^{\mathrm{b}}$ & 3.14 & 17.5 & 32.2 \\
\hline
\end{tabular}

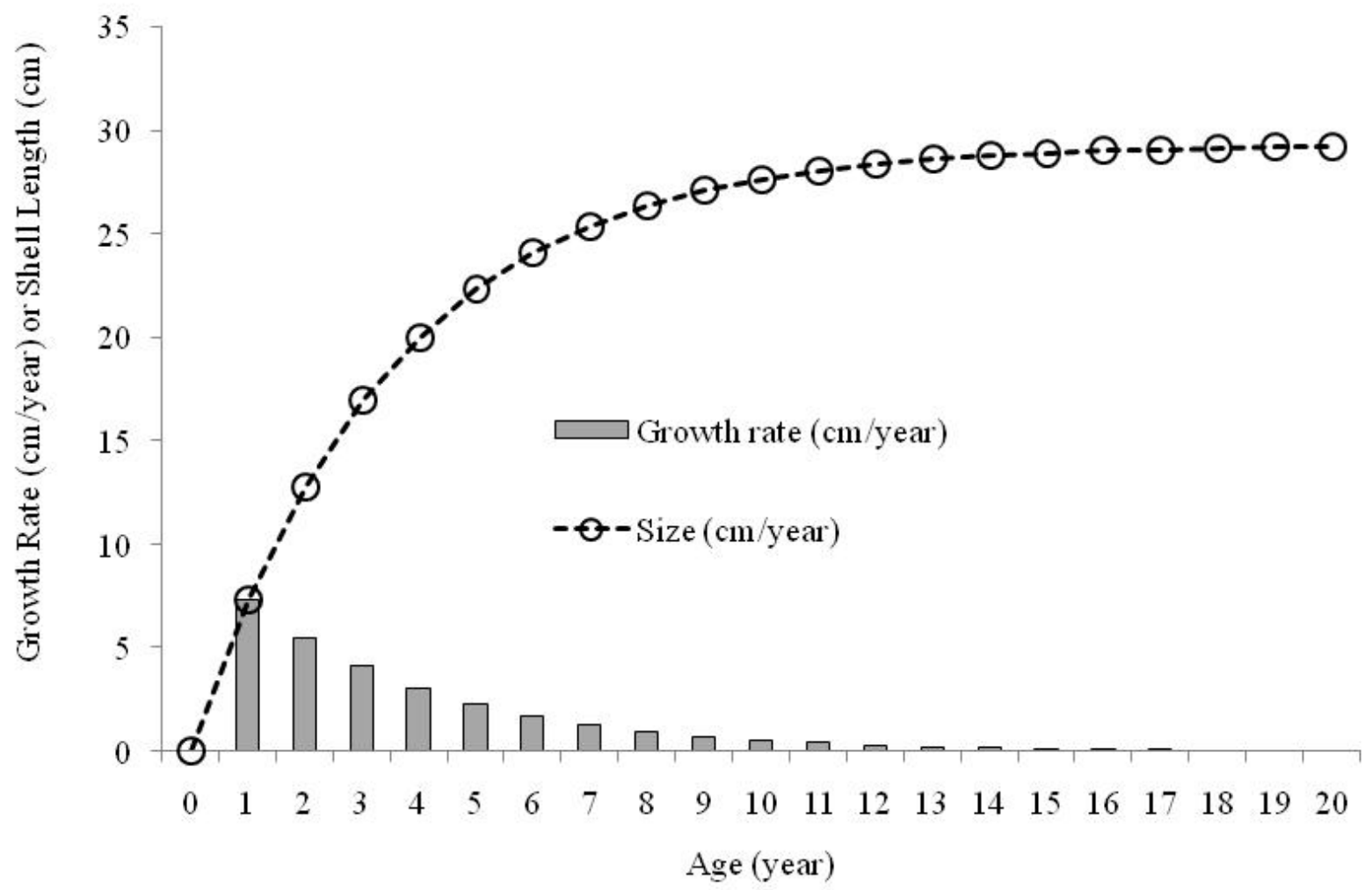

Figure 4. Predicted size at age and yearly growth rates of $H$. porcellanus in Tubbataha Reefs Natural Park obtained by substituting the $L \infty$ and $K$ values in the von Bertalanffy Growth Formula. 
In total, 88 of the clams were recovered alive at the end of the study period. Three empty shells were recovered and nine missing clams were assumed dead, thus total mortality was 12 individuals in 2.5 years (Table 2). This suggests $4.8 \%$ mortality per year and a life span of more than 20 years. This life span estimate coincides with the projected number of years at which the $L \infty$ could be attained (Figure 4).

Table 2. Number of marked Hippopus porcellanus that survived during the study period. A dash (-) indicates no data.

\begin{tabular}{|l|c|c|c|c|c|c|c|}
\hline \multicolumn{1}{|c|}{ Sampling } & Date & $\begin{array}{c}\text { No. of } \\
\text { days }\end{array}$ & $\begin{array}{c}\text { No. of live } \\
\text { clams } \\
\text { recovered } \\
\text { with tag }\end{array}$ & $\begin{array}{c}\text { No. of } \\
\text { live } \\
\text { clams } \\
\text { with lost } \\
\text { tag }\end{array}$ & $\begin{array}{c}\text { No. of } \\
\text { live clams }\end{array}$ & $\begin{array}{c}\text { No. of } \\
\text { missing } \\
\text { clams }\end{array}$ & $\begin{array}{c}\text { No. } \\
\text { of } \\
\text { dead } \\
\text { clams }\end{array}$ \\
\hline Initial & 29 Dec 2009 & 0 & - & - & 100 & - & - \\
\hline Second & 21 Dec 2010 & 357 & 94 & 2 & 96 & 4 & - \\
\hline Third & 13 Jun 2012 & 897 & 81 & 7 & 88 & 9 & 3 \\
\hline
\end{tabular}

\section{DISCUSSION}

Studies on shell dimension-live weight relationships have been reported for many bivalve species (Gaspar et al., 2001; Gimin et al., 2004) but not for live giant clams, possibly because of their large size, limited population and rock-burrowing habits of some species. Villanoy et al. (1988) only reported the relationships between shell lengths and empty shell weights for $H$. porcellanus and other giant clam species (Table 3). The established shell length-weight relationships are important for monitoring the growth in the natural population (Gimin et al. 2004). They also allow life history and morphological comparison between species and between populations of the same species from different habitats and localities, and can be used to estimate live weight and/or the biomass of the stock (see Gaspar et al., 2001).

Table 3. Estimated values of $a$ and $b$ in the length-shell weight relationships of different giant clam species of genera Hippopus and Tridacna in the Philippines. An asterisk (*) indicates measurements obtained from empty shells.

\begin{tabular}{|l|c|c|c|c|l|}
\hline \multicolumn{1}{|c|}{ Species } & $a$ & $b$ & $n$ & $r$ & \multicolumn{1}{c|}{ Source } \\
\hline H. porcellanus & 0.0000630 & 2.75741 & 80 & 0.97 & This study \\
\hline H. porcellanus & 0.0000318 & 3.37959 & 69 & 0.98 & Villanoy et al., 1988 \\
\hline H. hippopus & 0.0002900 & 2.78961 & 100 & 0.98 & Villanoy et al., 1988 \\
\hline T. squamosa & 0.0000379 & 3.50340 & 140 & 0.97 & Villanoy et al., 1988 \\
\hline T. gigas & 0.0000954 & 3.17109 & 160 & 0.96 & Villanoy et al., 1988 \\
\hline
\end{tabular}

The average $( \pm \mathrm{sd})$ shell length of $H$. porcellanus at marking was $21.98 \pm 5.27 \mathrm{~cm}$ with a range of $8.2-31.3 \mathrm{~cm}$. The $L \infty(29.24 \mathrm{~cm})$ is $10 \mathrm{~cm}$ less than the reported maximum size the clams can attain, but the average length in this study is similar to the reported common length in its distribution range (Poutiers, 1998a). The growth rate of $H$. porcellanus in this study is comparable to that of Tridacna derasa in village farms in the Solomon Islands; these reached an average SL of $15 \mathrm{~cm}$ in 2 years from an initial size range of $2-3 \mathrm{~cm}$ (Hart et al., 1998). It is also comparable with the growth rate $(5-8 \mathrm{~cm}$ per 
year) of Tridacna gigas in Eniwetok Atoll (see Yamaguchi, 1977). A little slower were the growth rates of $T$. maxima and $T$. crocea from the Solomon Islands. From an initial size range of 2-3 cm, T. maxima attained an average shell length of $7.8 \mathrm{~cm}$ in 19 months, while $T$. crocea reached an average of $5 \mathrm{~cm}$ after 22 months (Hart et al., 1998). Variations in growth within and among species (Table 4) could be attributed to various environmental conditions (Hart et al.,1998; Watson et al., 2012) and biological attributes of each species (Beckvar, 1981; Griffiths and Klumpp, 1996).

Table 4. The growth parameters for Hippopus porcellanus and other tridacnid species from other localities with comparable $L \infty$.

\begin{tabular}{|l|l|c|c|l|}
\hline \multicolumn{1}{|c|}{ Species } & \multicolumn{1}{c|}{ Country } & Lo $(\mathrm{cm})$ & $K$ & \multicolumn{1}{c|}{ Author } \\
\hline H. porcellanus & Philippines & 29.24 & 0.270 & This study \\
\hline H. porcellanus & Philippines & 43.60 & 0.130 & Villanoy et al., 1988 \\
\hline H. hippopus & Philippines & 43.70 & 0.130 & Villanoy et al., 1988 \\
\hline H. hippopus & Papua New Guinea & 40.00 & 0.213 & Munro and Heslinga, 1983 \\
\hline H. hippopus & Palau & 40.00 & 0.100 & Munro and Heslinga, 1983 \\
\hline T. maxima & Papua New Guinea & 30.50 & 0.112 & Munro and Heslinga, 1983 \\
\hline T. squamosa & Philippines & 30.00 & 0.230 & Villanoy et al., 1988 \\
\hline
\end{tabular}

Size at sexual maturity for $H$. pocellanus is not known, although Alcazar et al. (1987) had successfully induced a $16 \mathrm{~cm}$ clam to release sperm and a $31 \mathrm{~cm}$ clam to release eggs. If $H$. porcellanus become sexually mature at $16 \mathrm{~cm}$, such size is attainable within 3 years based on the predicted growth rates at TRNP. In Palau, spawning was successfully carried out on $H$. hippopus measuring $25 \mathrm{~cm}$ shell length (Jameson, 1976). Sexual maturity for T. maxima is attained upon reaching a shell length of 11-13 $\mathrm{cm}$, nearly $50 \%$ of its maximum shell length (Jameson, 1976).

Information on the life span of $H$. porcellanus in other countries is lacking. The estimated life span obtained in this study is comparable with age estimates for other giant clam species. Growth ring analysis on the shells of T. squamosa has shown that a $43 \mathrm{~cm}$ clam could be 22 years old (Basker, 1991). Estimates of life spans of other giant clam species are much longer. For example, a $24 \mathrm{~cm} \mathrm{T.} \mathrm{maxima}$ could be 40 years old, and the very large $(140 \mathrm{~cm})$ T. gigas could be 200 years old (Isamu, 2008). However, isotopic records on T. maxima $(\sim 20 \mathrm{~cm})$ suggest a life span of 28 years (Romanek et al., 1987). Watanabe et al. (2004) reported a 60 year isotopic record from the shell of a $93 \mathrm{~cm}$ long $T$. gigas. Longlived repeat breeding species like the giant clams are critical subjects for research because of their importance in the ecosystem (Cabaitan et al. 2008), in the economy (Andrefouet et al., 2005; Clarke et al., 2003; Gomez and Mingoa-Licuanan, 2006; Hart et al., 1998) and in providing useful information on past environmental settings (Aubert et al., 2009; Duprey et al., 2014). As growth rates among clams could vary between regions or among reefs, studies on aspects of the biology of other giant clam species in TRNP and in other parts of Palawan is suggested.

\section{ACKNOWLEDGEMENTS}

This study was made possible through the help of the composite team of Rangers assinged at TRNP from December 2009 through January 2010. Dr. Lota A. Creencia provided constructive comments and suggestions on the early draft of the manuscript. 


\section{REFERENCES}

Alcazar, S.N., E.P. Solis and A.C. Alcala.1987. Serotonin-induced spawning and larval rearing of the China clam, Hippopus porcellanus Rosewater (Bivalvia: Tridacnidae). Aquaculture, 66:359-368.

Andrefouet, S., A. Gilbert, L. Yan, G. Remoissenet, C. Payri and Y. Chancerelle. 2005. The remarkable population size of the endangered giant clam Tridacna maxima assessed in Fangatau Atoll (Eastern Tuamotu, French Polynesia) using in situ and remote sending data. ICES Journal of Marine Science, 62:1037-1048.

Aubert, A., C.E. Lazareth, G. Cabioch, H. Boucher, T. Yamada, Y. Iryu and R. Farman. 2009. The tropical giant clam Hippopus hippopus shell, a new archive of environmental conditions as revealed by sclerochronological and $\delta^{18} \mathrm{O}$ profiles. Coral Reefs, 28:989-998.

Basker JR. 1991. Giant clams in the Maldives - a stock assessment and study of their potential for culture. Bay of Bengal Programme, Reef Fish Research and Resources Survey: Food and Agriculture Organisation of the United Nations.

Beckvar, N. 1981. Cultivation, spawning, and growth of the giant clams Tridacna gigas, T. derasa, and $T$. squamosa in Palau, Caroline Islands. Aquaculture, 24:21-30.

Cabaitan, P.C., E.D. Gomez and P.M. Aliño. 2008. Effects of coral transplantation and giant clam restocking on the structure of fish communities on degraded patch reefs. Journal of Experimental Marine Biology and Ecology, 357(1):85-98.

Calumpong, H.P. and P. Cadiz.1993. Observations on the distribution of giant clams in protected areas. Silliman Journal, 36(2):107-113.

CITES. 2014. Convention on International Trade in Endangered Species of Wild Fauna and Flora: Appendices I, II and III. www.cites.org/eng/app/appendices.php. Accessed on April 20, 2014.

Clarke, P.J., T. Komatsu, J.D. Bell, F. Lasi, C.P. Oengpepa and J. Leqata.2003. Combined culture of Trochus niloticus and giant clams (Tridacnidae): benefits for restocking and farming. Aquaculture, 215(1-4):123-144.

Dolorosa, R.G., A. Grant and J.A. Gill.2013. Translocation of wild Trochus niloticus: prospects for enhancing depleted Philippine reefs. Reviews in Fisheries Science, 21(3-4):403-413.

Dolorosa, R.G. and J.B.S. Jontila.2012. Notes on common macrobenthic reef invertebrates of Tubbataha Reefs Natural Park, Philippines. Science Diliman, 24(2):1-11.

Duprey, N., J.-C.Galipaud, G. Cabioch, and C.E. Lazareth. 2014. Isotopic records from archeological giant clams reveal a variable climate during the southwestern Pacific colonization ca. $3.0 \mathrm{ka} \mathrm{BP}$. Palaeogeography, Palaeoclimatology, Palaeoecology, 404:97-108.

Estacion, J., V. Palaganas, R. Perez and M. Alava.1993. Benthic characteristics of Islands and Reefs in the Sulu Sea, Philippines. Silliman Journal,36(2):15-44.

Foyle, T.P., J.D. Bell, M. Gervis and I. Lane.1997. Survival and growth of juvenile fluted giant clams, Tridacna squamosa, in large-scale grow-out trials in the Solomon Islands. Aquaculture, 148(2-3):85104.

Gaspar, M.B., M.N. Santos and P. Vasconcelos. 2001. Weight-length relationships of 25 bivalve species (Mollusca: Bivalvia from the Algarve coast (southern Portugal). Journal of Marine Biology Ass. U.K., 81:805-807.

Gimin, R., R. Mohan, L.V. Thinh and A.D. Griffiths. 2004. The relationship of shell dimensions and shell volume to live weight and soft tissue weight in the mangrove clam, Polymesoda erosa (Solander, 1786) from northern Australia. NAGA, WorldFish Center Quarterly, 27 (3\& 4):32-35.

Gomez, E.D. and S.S. Mingoa-Licuanan.2006. Achievements and lessons learned in restocking giant clams in the Philippines. Fisheries Research, 80(1):46-52.

Griffiths, C.L. and D.W.Klumpp.1996. Relationships between size, mantle area and zooxanthellae numbers in five species of giant clam (Tridacnidae). Marine Ecology Progress Series, 137:139-147.

Hart, A.M., J.D. Bell and T.P.Foyle.1998. Growth and survival of the giant clams, Tridacna derasa, T. maxima and T. crocea, at village farms in the Solomon Islands. Aquaculture, 165(3-4):203-220. 
Isamu, T. 2008. Palau Case Study- Tridacnidae. In NDF Workshop Case Studies, WG 9-Aquatic Invertebrates, Palau.

Jameson, S.C. 1976. Early life history of the Giant clams Tridacna crocea Lamarck, Tridacna maxima (Röding), and Hippopus hippopus (Linnaeus). Pacific Science,30(3):219-233.

Juinio, M.A.R., L.A.B. Meñez, C.L. Villanoy and E.D. Gomez.1989. Status of giant clam resources in the Philippines. Journal of Molluscan Studies, 55:431-440.

Munro, J. and G. Heslinga.1983. Prospects for commercial utilization of giant clams (Bivalvia: Tridacnidae). Proceedings of the Gulf and Caribbean fisheries Institute,35:122-134.

Neo, M.L. and P.A. Todd. 2013. Conservation status reassessment of giant clams (Mollusca: Bivalvia: Tridacninae) in Singapore. Nature in Singapore, 6:125-133.

Ogle, D.H.2010. FSA - package in R. http://www.rforge.net/FSA/index.html.

Othman, A.S.B., G.H.S. Goh and P.A. Todd. 2010. The distribution and status of giant clams (Family Tridacnidae) - a short review. Raffles Bulletin of Zoology, 58(1):103-111.

Poutiers, J.M. 1998a. Bivalves (Acephala, Lamellibranchia, Pelecypoda). In K.E. Carpenter and V.H. Niem (Eds) FAO species identification guide for fishery purposes. The Living Marine Resources of the Western Central Pacific. Seaweeds, Corals, Bivalves and Gastropods, vol. 1, pp. 123-362. FAO, Rome.

Poutiers, J.M. 1998b. Gastropods. In K.E. Carpenter and V.H. Niem (Eds) FAO species identification guide for fishery purposes. The Living Marine Resources of the Western Central Pacific. Seaweeds, Corals, Bivalves and Gastropods, vol. 1, pp. 364-686. FAO, Rome.

R. (2011) R: A Language and Environment for Statistical Computing. Vienna, Austria: R Foundation for Statistical Computing.

Romanek, C.S., D.S. Jones, D.F. Williams, D.E. Krantz and R. Radtke.1987. Stable isotopic investigation of physiological and environmental changes recorded in shell carbonate from the giant clam Tridacna maxima. Marine Biology, 94:385-393.

Su, Y., J.-H.Hung, H. Kubo and L.-L.Liu. 2014. Tridacna noae (Röding, 1798) - a valid giant clam species separated from T. maxima (Röding, 1798) by morphological and genetic data. Raffles Bulletin of Zoology, 62:124-135.

Tan, S. and Y. Zulfigar. 2003. Status of giant clams in Malaysia. SPC Trochus Information Bulletin, 10:910.

Villanoy, C.L., A.R. Juinio and L.M. Meñez.1988. Fishing mortality rates of giant clams (Family Tridacnidae) from Sulu Archipelago and Southern Palawan, Philippines. Coral Reefs, 7:1-5.

Watanabe, T., A. Suzuki, H.Kawahata, H. Kan and S. Ogawa. 2004. A 60-year isotopic record from a mid-holocene fossil giant clam (Tridacna gigas) in the Ryukyu Islands: physiological and paleoclimatic implications. Palaeogeography Palaeoclimatology Palaeoecology, 212:343-354.

Yamaguchi, M. 1977.Conservation and cultivation of giant clams in the tropical Pacific. Biological Conservation, 11(1):13-20.

Watson, S-A., P.C. Southgate, G.M. Miller, J.A. Moorhead and J. Knauer. 2012. Ocean acidification and warming reduce juvenile survival of the fluted giant clam, Tridacna squamosa. Molluscan Research, 32(3):177-180. 